\title{
Magnetic core-shell nanoparticles for drug delivery by nebulization
}

\author{
Navin Kumar Verma ${ }^{1,2^{*}}$, Kieran Crosbie-Staunton ${ }^{1,2}$, Amro Satti ${ }^{2,3}$, Shane Gallagher ${ }^{2,3}$, Katie B Ryan ${ }^{4}$, \\ Timothy Doody ${ }^{4}$, Colm McAtamney ${ }^{2}$, Ronan MacLoughlin ${ }^{5}$, Paul Galvin ${ }^{6}$, Conor S Burke ${ }^{7}$, Yuri Volkov ${ }^{1,2+}$ \\ and Yurii K Gun'ko $2,3+$
}

\begin{abstract}
Background: Aerosolized therapeutics hold great potential for effective treatment of various diseases including lung cancer. In this context, there is an urgent need to develop novel nanocarriers suitable for drug delivery by nebulization. To address this need, we synthesized and characterized a biocompatible drug delivery vehicle following surface coating of $\mathrm{Fe}_{3} \mathrm{O}_{4}$ magnetic nanoparticles (MNPs) with a polymer poly(lactic-co-glycolic acid) (PLGA). The polymeric shell of these engineered nanoparticles was loaded with a potential anti-cancer drug quercetin and their suitability for targeting lung cancer cells via nebulization was evaluated.
\end{abstract}

Results: Average particle size of the developed MNPs and PLGA-MNPs as measured by electron microscopy was 9.6 and $53.2 \mathrm{~nm}$, whereas their hydrodynamic swelling as determined using dynamic light scattering was $54.3 \mathrm{~nm}$ and $293.4 \mathrm{~nm}$ respectively. Utilizing a series of standardized biological tests incorporating a cell-based automated image acquisition and analysis procedure in combination with real-time impedance sensing, we confirmed that the developed MNP-based nanocarrier system was biocompatible, as no cytotoxicity was observed when up to $100 \mathrm{\mu g} / \mathrm{ml}$ PLGA-MNP was applied to the cultured human lung epithelial cells. Moreover, the PLGA-MNP preparation was well-tolerated in vivo in mice when applied intranasally as measured by glutathione and IL-6 secretion assays after 1, 4, or 7 days post-treatment. To imitate aerosol formation for drug delivery to the lungs, we applied quercitin loaded PLGA-MNPs to the human lung carcinoma cell line A549 following a single round of nebulization. The drug-loaded PLGA-MNPs significantly reduced the number of viable A549 cells, which was comparable when applied either by nebulization or by direct pipetting.

Conclusion: We have developed a magnetic core-shell nanoparticle-based nanocarrier system and evaluated the feasibility of its drug delivery capability via aerosol administration. This study has implications for targeted delivery of therapeutics and poorly soluble medicinal compounds via inhalation route.

Keywords: Nanomedicine, Magnetite nanoparticles, Quercetin, Drug delivery, Nebulization

\section{Background}

The development of nanoparticles as controlled drug delivery and disease detection systems has emerged as one of the most promising biomedical and bioengineering applications of nanotechnology. Magnetic nanoparticles, in particular iron oxide (also called magnetite or $\mathrm{Fe}_{3} \mathrm{O}_{4}$ )

\footnotetext{
* Correspondence: verman@tcd.ie

${ }^{\dagger}$ Equal contributors

'Department of Clinical Medicine, Institute of Molecular Medicine, Trinity College Dublin, Dublin, Ireland

${ }^{2}$ Centre for Research on Adaptive Nanostructures and Nanodevices, Trinity College Dublin, Dublin, Ireland

Full list of author information is available at the end of the article
}

nanoparticles (MNPs) and their multifunctionalized counterparts are an important class of nanoscale materials that have attracted great interest for their potential applications in drug delivery and disease diagnosis [1-5]. Owing to the recent advances in synthesis and surface modification technologies, a variety of new potential applications have become feasible for this class of nanomaterials that may revolutionise current clinical diagnostic and therapeutic techniques.

The well-developed surface chemistry of $\mathrm{Fe}_{3} \mathrm{O}_{4}$ MNPs allows loading of a wide range of functionalities, such as

\section{Biomed Central}


targeting ligands, imaging and therapeutic features onto their surfaces. It is now possible to fine-tune the physical parameters of MNPs, such as size, shape, crystallinity, and magnetism $[3,4]$. Furthermore, MNPs have the potential for replacement or modification of the coating materials post-synthesis allowing tailoring of the nanoparticle's surface charge, chemical groups, and overall size [4-6]. Due to their unique physicochemical properties and ability to function at the cellular and molecular level of biological systems, MNPs are being actively investigated as the next generation of targeted drug delivery vehicle. The design of such drug delivery systems requires that the carriers be capable of selectively releasing their payloads at specific sites in the body and thereby treat disease deliberately without any harmful effect on the healthy tissues. In this regard, MNPs represent a promising option for selective drug targeting as they can be concentrated and held in position by means of an external magnetic field. This allows high dose drug-loads to be delivered to a desired target tissue while minimizing the exposure of healthy tissues to the side effects from highly toxic drugs, e.g. chemotherapeutic agents. In addition, preclinical and clinical studies have proven them to be safe and some formulations are now FDA approved for clinical imaging and drug delivery [7]. In particular, MNPs are being extensively utilized as a magnetic resonance imaging contrast agents to detect metastatic infestation in lymph nodes (such as Combidex $^{\circledR}$, Resovist ${ }^{\circledR}$, Endorem ${ }^{\circledR}$, Sinerem ${ }^{\circledR}$ ), give information about tumor angiogenesis, identify dangerous atherosclerosis plaques, follow stem cell therapy, and in other biomedical research [8-11]. Further, functionalized multimodal MNPs are being widely explored for numerous other biomedical applications including magnetic guidance of drugs encapsulated by magnetic particles to target tissues (for example tumor) where they are retained for a controlled treatment period [2,12-22]. Thus, fabrication of MNPs as drug conjugates has the potential to greatly benefit inflammatory disease and cancer treatments, and diagnostics.

Aerosolised therapeutics has emerged as a promising alternative to systemic drug delivery for the treatment or prevention of a variety of lung diseases such as asthma, chronic obstructive pulmonary disease, respiratory infection, and lung cancer [23-26]. An aerosol-mediated approach to lung cancer therapy holds promise as a means to improve therapeutic efficiency and minimize unwanted systemic toxicity. A number of drugs have been investigated in vitro, in animal models and in human trials as targeted aerosol chemotherapy for lung cancer [25-31]. A range of nebulizer systems designed for individualised and controlled preparations of therapeutic aerosols have been developed and validated (e.g. Aerogen's Aeroneb ${ }^{\circledR}$ Pro nebuliser) for aerosol therapy.
The aim of this work was to establish a biocompatible MNP-based drug delivery system suitable for nebulization and inhalation targeting of therapeutics for the treatment of lung diseases. The schematic structure of the nanocarrier-drug composite is given in Figure 1. In order to improve the dispersion in aqueous medium, stability against oxidation and biocompatibility of the delivery system, MNP surface was coated with a biopolymer poly(DL-lactic-co-glycolic acid) (PLGA). In this study, we selected a poorly soluble flavonoid quercetin to act as a model drug, since it has demonstrated the potential for growth inhibition of a variety of human cancers including lung cancer [32,33]. The biocompatibility of the developed nanocarrier system was tested in vitro and in vivo, and the feasibility of a novel vibrating mesh nebulization technique was investigated for the delivery of drug-loaded MNPs to the cultured human lung cancer cells. Thus, to our knowledge, this is the first study that reports the potential of magnetic core-shell nanoparticles loaded with a poorly soluble compound quercetin for aerosol delivery by nebulization.

\section{Results}

\section{Preparation and characterization of surface engineered MNPs}

As evident from the analysis using transmission electron microscopy (TEM) the average size of the uncoated MNPs was $9.6 \pm 1.3 \mathrm{~nm}$, which was increased to $53.2 \pm 6.9 \mathrm{~nm}$ following coating with PLGA (Figure 2A). The dynamic light scattering (DLS) measurements showed that the average hydrodynamic diameter of MNP and PLGA-MNP was $54.3 \pm 8.7 \mathrm{~nm}$ and $293.4 \pm 31.9 \mathrm{~nm}$ respectively. Magnetisation measurement of MNP was confirmed by its superparamagnetic properties (Figure $2 \mathrm{~B}$ ). After purification, a stock solution of $1 \mathrm{mg} / \mathrm{ml}$ was made for both the MNP preparations and stored at room temperature. The PLGA-MNP samples were stable in phosphate buffered saline (PBS) and in physiological buffers.

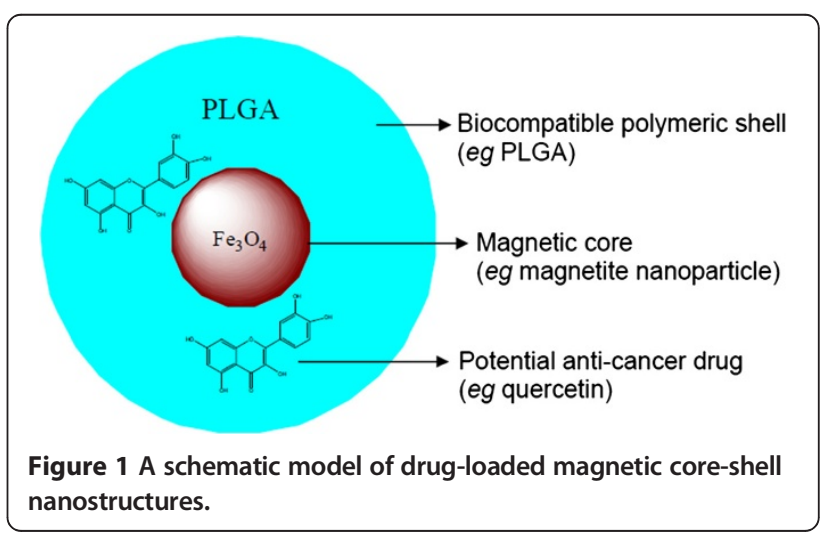




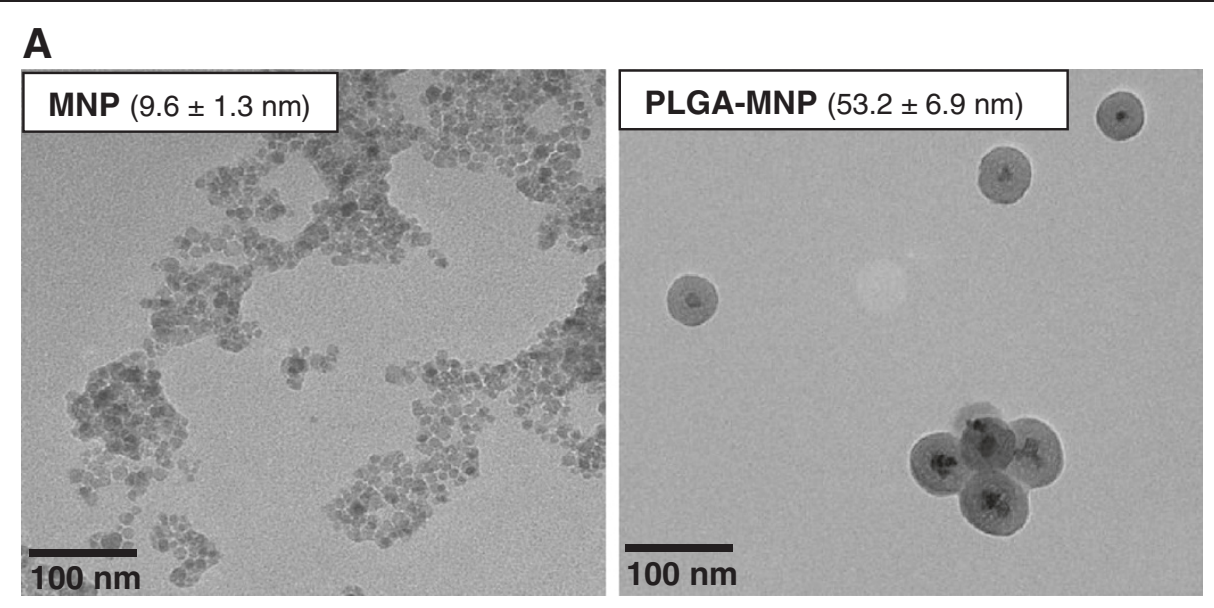

B

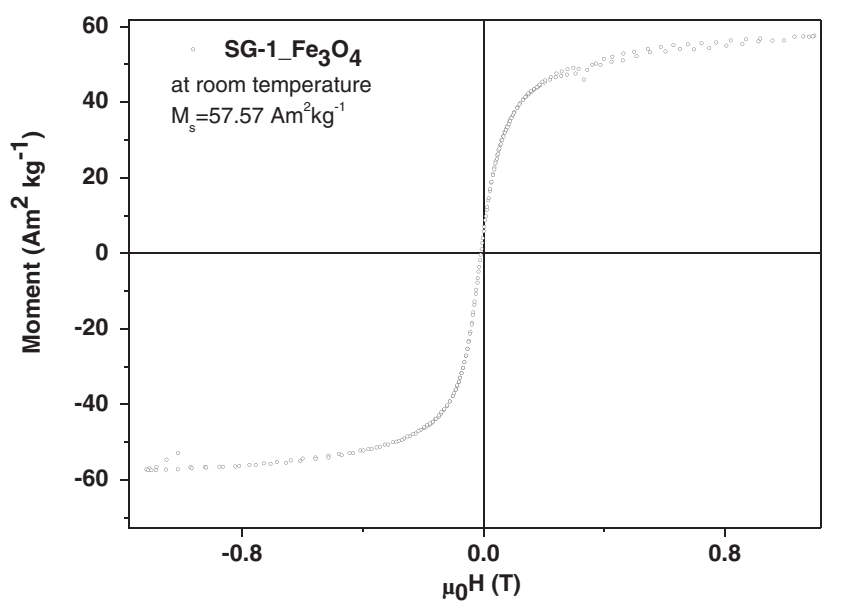

Figure 2 TEM images and magnetisation curve of initial MNPs. A. MNPs or PLGA coated MNPS (PLGA-MNP) were imaged by TEM and presented. The average size of both the MNPs was measured as indicated on the corresponding images. $\mathbf{B}$. Magnetisation curve of initial $\mathrm{Fe}_{3} \mathrm{O}_{4}$ MNP at room temperature.

\section{In vitro biocompatibility analysis of engineered MNPs}

To investigate the biological safety of the developed nanocarriers, the cell-MNP interaction by means of cellular accumulation and their cytocompatibility on human A549 lung epithelial cells was performed in vitro. Initially we examined the morphology of A549 cells exposed to MNP or PLGA-MNP $(50 \mu \mathrm{g} / \mathrm{ml}$ each) for $24 \mathrm{~h}$ by a cell-based automated microscope. Compared to the control untreated cells, no detectable change in the gross structure of the cytoskeletal protein actin (Figure 3A, fluorescent images) or the morphology of cells exposed to MNP or PLGA-MNP were detected (Figure 3A, bright field images). The overall shapes and sizes of cells and nuclei were within the normal variation range and there were no signs of cellular or nuclear abnormalities, membrane bound vesicles, or cell rupture (Figure 3A). No significant change in the cell morphology parameters including cell and nuclear areas and fluorescent intensities was observed following exposure to MNP or PLGA-MNP as compared to that with untreated cells. Cellular accumulation of MNP or PLGA-MNP was detected in treated cells (Figure 3A, brightfield images in the middle panel and insets in the right panel). We quantified the number of cells with accumulated MNPs over time, which included internalized MNPs and MNPs adhering to the cell surface, by In Cell Investigator software (GE Healthcare, UK). Results showed a time-dependent increase in the cellular association of MNPs, where more than $50 \%$ cells with accumulated MNPs at $4 \mathrm{~h}$ and over $75 \%$ cells with accumulated MNPs at $8 \mathrm{~h}$ and $24 \mathrm{~h}$ were detected (Figure 3B).

The cytocompatibility analysis of MNP and PLGAMNP in A549 cells by high content screening (HCS) demonstrated that both the MNP preparations were non-toxic $(<10 \%$ reduction in viable cell number) at concentrations up to $100 \mu \mathrm{g} / \mathrm{ml}$ (Figure 3C). However, a moderate but significant reduction $(\sim 25 \%)$ in the 


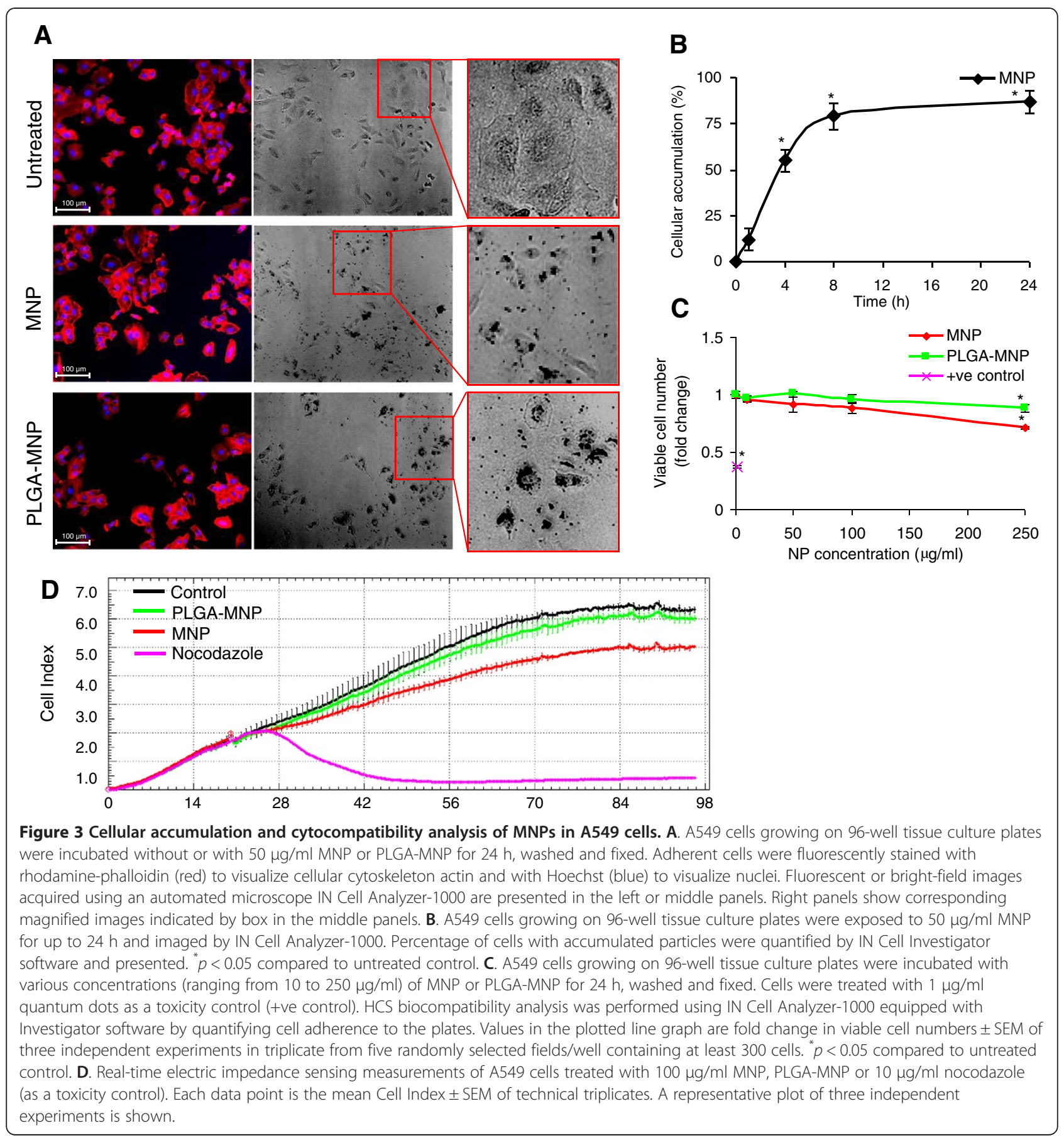

number of viable A549 cells following 24 h exposure to MNP preparations was observed at a high concentration of $250 \mu \mathrm{g} / \mathrm{ml}$ (Figure 3C). We further evaluated the biocompatibility of MNP and PLGA-MNP $(100 \mu \mathrm{g} / \mathrm{ml}$ each) in A549 cells in real-time for up to $76 \mathrm{~h}$ using a whole cell-based electrical impedance sensing technique utilizing xCELLigance instrument (Roche Applied Science, West Sussex, UK). Untreated cells seeded onto the gold electrode array of the impedance assay E-plates (supplied by Roche Applied Science, West Sussex, UK) at a density of $5 \times 10^{3}$ cells/well showed a continuous increase in impedance (expressed as an arbitrary unit Cell Index) over time as the cells attach, spread and form a stable confluent monolayer on the surface of the E-plate (Figure 3D). When A549 cells were treated with uncoated MNPs $(100 \mu \mathrm{g} / \mathrm{ml})$ at $20 \mathrm{~h}$ after cell seeding onto the E-plate, a low level of decrease in the Cell Index was detected over time; whereas or PLGA-MNPs did not 
cause any significant change in the Cell Index relative to untreated cells (Figure 3D). In contrast, a sharp decrease in the Cell Index was detected when A549 cells were treated with a toxic compound nocodazole (Figure 3D).

\section{In vivo biocompatibility analysis of engineered MNPs}

The biocompatibility of MNPs surface engineered with a PLGA polymer coat was also assessed in vivo using a mouse model. Homogenised mouse lung samples were assayed for total glutathione levels (both GSH and GSSH) as an indicator of oxidative stress after 1, 4, and 7 days post-exposure to uncoated MNP, PLGA-MNP or lipopoysaccharide (LPS, used as a positive control). Lung samples obtained 1 day after intranasal administration showed a dramatic increase in the glutathione levels in the case of all samples (Figure 4A), which may possibly be attributed to the invasive nature of intratracheal administration. However, the glutathione levels in the lung tissue were reduced 4 days after treatment with MNP or PLGA-MNP and continued to decrease thereafter (Figure 4A). In contrast, glutathione levels in mice treated with LPS remained elevated over the 7 day test period (Figure 4A). Analysis of IL-6 levels in bronchoalveolar lavage (BAL) fluid samples from treated mice measured at 1, 4 and 7 days subsequent to intranasal administration of the MNP formulations and the LPS control (Figure 4B). After 1 day, a significant increase in IL-6 levels in the case of the LPS control was observed, but this returned to background level 4 days post treatment, whereas mice treated with uncoated MNP or PLGA-MNP displayed no significant increase in IL-6 levels relative to naïve animals at any time points post-treatment.

\section{Efficacy analysis of quercetin-loaded MNPs delivered in vitro by nebulization}

We incorporated a model drug quercetin in the PLGAMNP and then characterized by photoluminescence before and after nebulization. No significant change in intensity and position (no shift) of the bands in the photoluminescence spectra (excited at $380 \mathrm{~nm}$ ) was detected due to nebulization, confirming that the particles were intact and not adversely affected by the process of nebulization (Figure 5).

To evaluate the therapeutic efficacy of quercetinloaded PLGA-MNPs, they were applied to the human A549 lung carcinoma cells. A549 cells seeded in 96-well plates were exposed to varying doses of PLGA-MNP or quercetin-loaded PLGA-MNP (ranging from $31.25 \mu \mathrm{g} / \mathrm{ml}$ to $250 \mu \mathrm{g} / \mathrm{ml}$ ) by direct pipetting or by nebulization and incubated for $24 \mathrm{~h}$. The ability of quercetin present in the PLGA-MNP to cause cell death of A549 cells was analysed using HCS assay by quantifying the number of viable adherent cells (Figure 6). No significant change in the number of adherent cells was observed following exposure to PLGA-MNP (Figure 6). In contrast, quercetin-loaded PLGA-MNP, applied to cells either by direct pipetting (Figure 6A) or by nebulization (Figure 6B) and incubated for $24 \mathrm{~h}$, significantly reduced the number of viable A549 cells. These data confirmed the in vitro therapeutic efficacy of the quercetin-loaded PLGA-MNP.

\section{Discussion}

There is currently significant worldwide effort to develop, fabricate and characterize novel nanoscale materials for a variety of novel applications. In the present work, we have developed procedures to prepare novel
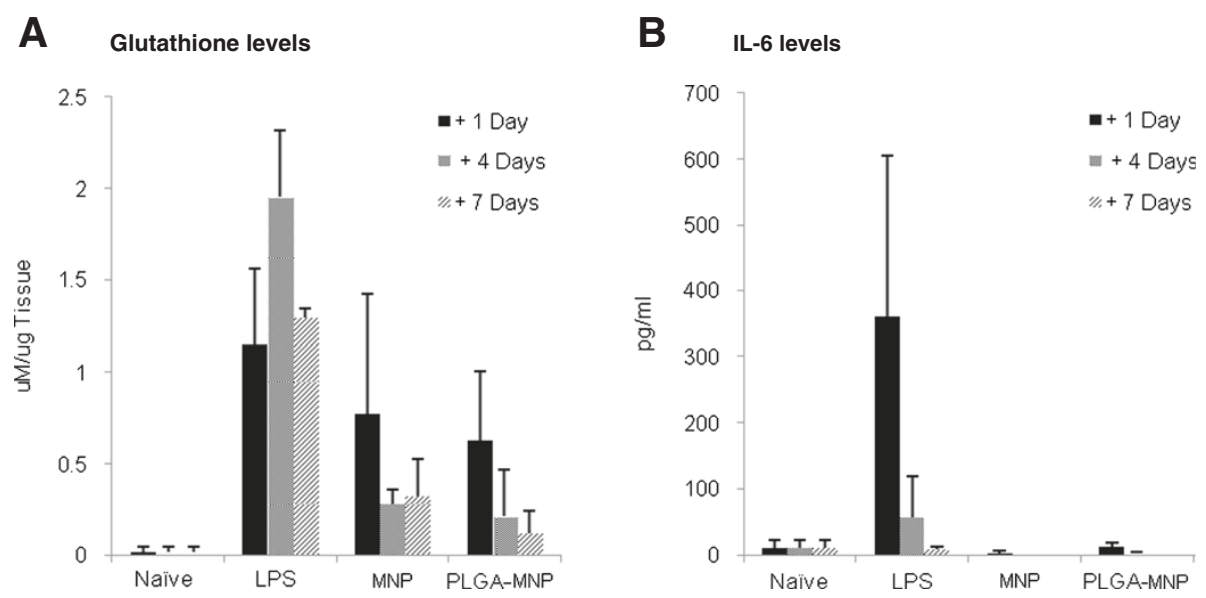

Figure 4 In vivo biocompatibility analysis of MNPs. A. Measurement of total glutathione levels in lung tissue from mice treated with a single intranasal delivery. Lungs were harvested from treated mice at 1, 4 and 7 days post-treatment with uncoated MNP, PLGA-MNP or LPS (used as a positive control). B. Measurement of IL-6 levels in BAL fluid from mice treated with a single intranasal delivery. BAL fluid was obtained from treated mice at 1, 4 and 7 days post-treatment with MNP, PLGA-MNP or LPS. Data are mean \pm SEM of at least 3 animals under each treatment conditions. 


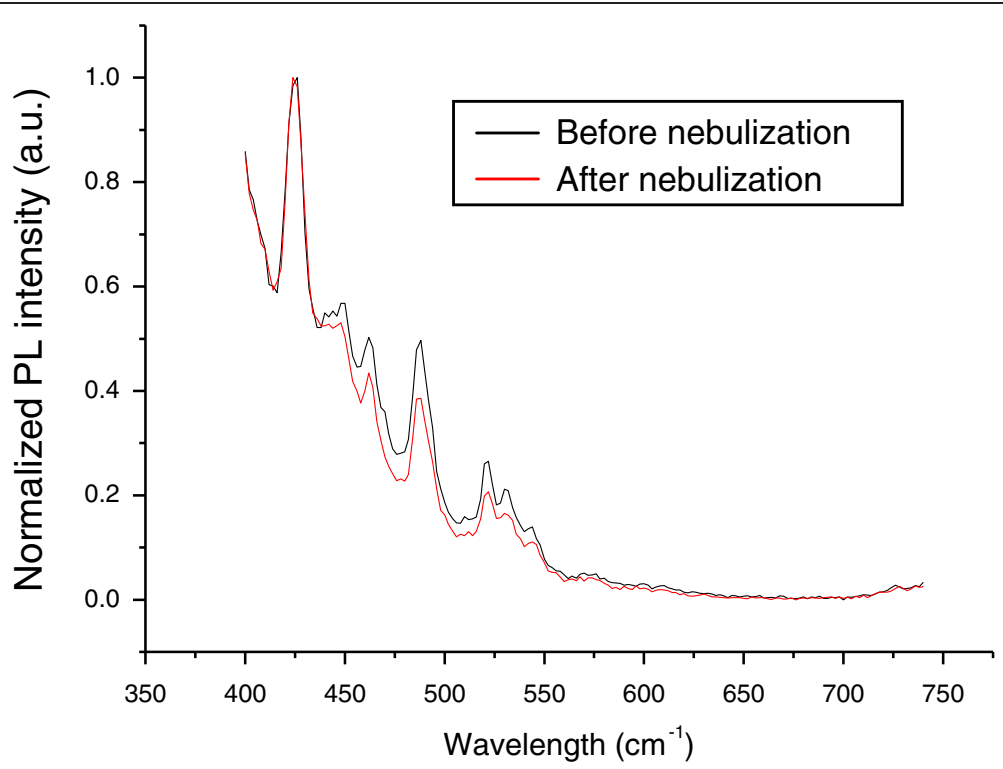

Figure 5 Photoluminescence spectra of quercetin-loaded PLGA-MNP before and after nebulization. Spectra show normalised photoluminescence (PL) intensities (a.u., arbitrary units) against wavelength (nm).

biocompatible MNPs that possessed suitable properties for biomedical applications. Biocompatibility of the developed MNPs was characterized in vitro (the influence of MNPs was assessed in terms of cell viability, cellular and nuclear morphology, and observations of actin cytoskeleton) and in vivo (the influence of MNPs on glutathione and IL-6 secretion in mice). The developed MNPs were successfully loaded with a promising anti-cancer drug quercetin. Further, in this study we described a novel method of drug-loaded nanoparticle delivery to lung cancer using aerosols. The optimised proof-of-concept nanoplatform documented in the present study can further be exploited to load functionalities onto the MNP surfaces via various mechanisms with broad implications for pharmacotherapies, drug delivery and molecular imaging.

A targeted drug delivery system requires the design of carriers capable of selectively releasing their payloads at specific sites in the body. Although a number of nanosize materials are being exploited for drug delivery purposes including for example PLGA nanoparticles [34,35], MNPs represent a highly promising option for selective

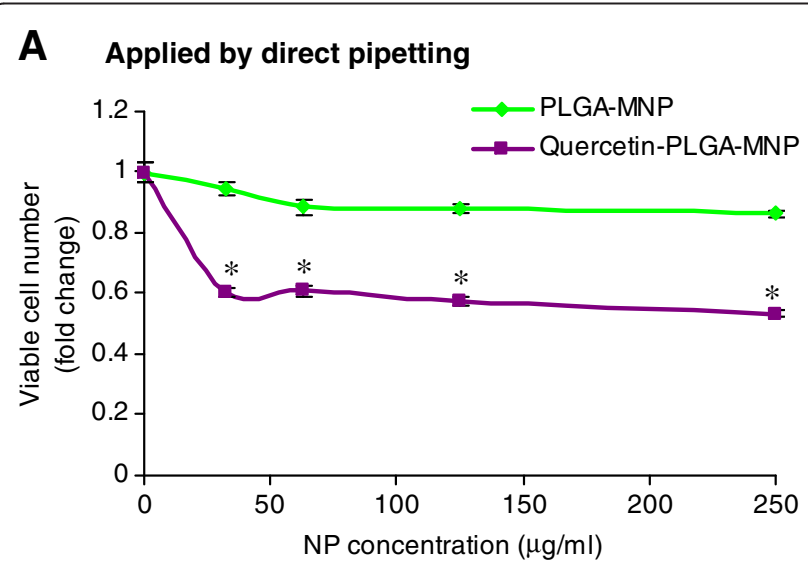

B Applied by nebulization

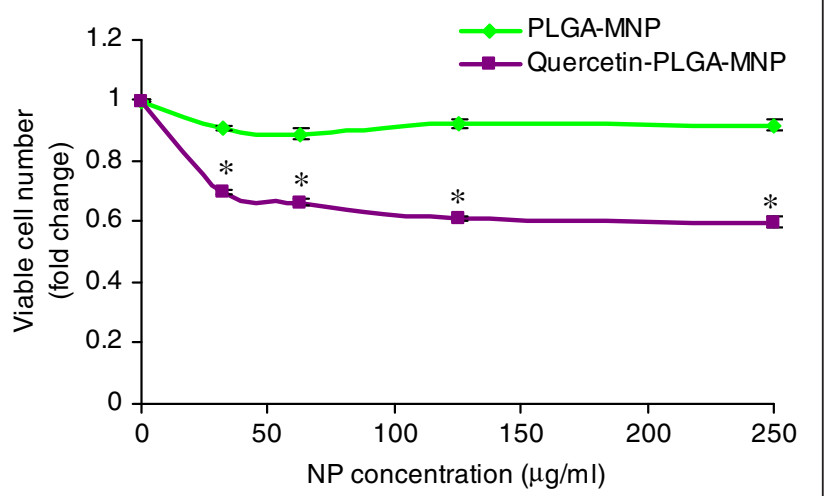

Figure 6 Comparative analysis of the efficacy of quercitin-loaded PLGA-MNP delivered to A549 cells via direct pippetting or nebulization. A549 cells growing on 96-well tissue culture plates were exposed to various concentrations (ranging from 10 to $250 \mu \mathrm{g} / \mathrm{ml}$ ) of empty or quercitin-loaded PLGA-MNP by direct pippetting (A) or nebulization (B). Following treatment, cells were incubated for $24 \mathrm{~h}$, washed and fixed. HCS assay was performed using IN Cell Analyzer-1000 equipped with Investigator software by quantifying cell adherence to the plates. Values in the plotted as line graph are fold change in viable cell numbers \pm SEM of three independent experiments in triplicate from five randomly selected fields/well containing at least 300 cells. ${ }^{*} p<0.05$. Quercetin alone could not be used as a control due to its poor aqueous solubility. 
drug targeting as they exhibit a wide variety of desirable attributes. In particular, they can be concentrated and held in position with the aid of an external magnetic field. The deposition, accumulation, and retention of drug-conjugated MNPs in target tissue can thus be enhanced by magnetic guidance. Such magnetic targeting allows very concentrated drug doses to be delivered to specific area while minimizing the exposure of healthy tissues to uncontrollable highly toxic therapeutic substances; e.g. chemotherapeutic agents. Moreover, the superparamagnetic behaviour of MNPs provides multifunctional effects such as controlled heating capability under an alternating magnetic field, which has demonstrated tremendous promise as theranostics for the detection and treatment of cancer [7,9,36,37]. In addition, iron oxides occur naturally in human heart, spleen and liver [38], which supports the biocompatibility and nontoxicity of MNPs at a physiological concentration. Due to the above-mentioned favorable features and versatility, in our opinion, $\mathrm{Fe}_{2} \mathrm{O}_{3}$ MNPs would serve as an excellent core material for a nano carrier system particularly suitable for the controlled aerosol drug delivery.

To date a wide variety of MNPs have been developed by several researchers, differing in size and type of coating materials used [7-13,39-42]. Some preparations are currently in preclinical or clinical use in intracellular hyperthermia treatments and MRI contrast agents [7,9]. It is important to note that in order to improve the size distribution of MNPs and prevent their aggregation in aqueous solution these nanoparticles have to be coated with materials that keep particles apart. However, there is quite contradictory information on the effect of magnetic nanoparticles - biopolymer core-shell structures on cytotoxicity. It has been suggested that upon internalization, the coating shell on the MNPs may be broken down yielding particle chains and aggregates, which may influence biological processes $[42,43]$. In this study, we modified the surface of $\mathrm{Fe}_{3} \mathrm{O}_{4}$ MNPs by coating them with a biocompatible polymeric material PLGA, which has been proven to be beneficial for nanoparticle coating purposes with no measurable toxicity reported $[42,44]$.

In order to evaluate the biocompatibility of developed MNPs, we performed a series of in vitro assays using a human lung alveolar epithelial cell line A549 and in vivo studies using normal Balb/c mice. The carcinomaderived A549 cells are a well-characterised in vitro lung epithelial model and have been extensively used for assessing cytotoxicity, including nanomaterials-induced cytotoxicity [45-47]. Additionally, A549 cells display similar uptake and toxicity of nanoparticles as compared to normal primary lung epithelial cells, although both cell types respond differentially for the release of cytokines involved in inflammatory reactions [48]. Based on these reports and our data from in vitro as well as in vivo experiments presented here, we expect that the developed MNPs will have similar effect(s) on normal lung epithelial cells in terms of their cytocompatibility. However, a detailed characterization of MNPs on normal lung cells should be performed before their potential clinical applications in drug delivery.

We employed the use of HCS in combination with an impedance-based assay for the biocompatibility analysis of MNP preparations. The HCS assay utilizes a novel quantitative imaging technique and offers rapid analysis of toxicity (if any) at cellular level [46,47]; whereas, impedance sensing allows a kinetic profile of cytotoxicity (if any), and maps the processes that cells undergo when challenged with nanoparticles such as MNPs [49,50]. Since the insulating properties of cells are based on whole cell structure, cellular responses such as cell death, proliferation, spreading and attachment can be detected by impedance measurements $[49,50]$. This cellbased label-free non-invasive detection method thus not only provides toxicity data, but also can identify a timeframe during which further targeted analysis can be performed. Both HCS and impedance measurement assays confirmed that MNPs developed in the present work were not toxic to A549 cells up to a concentration of $100 \mu \mathrm{g} / \mathrm{ml}$, although a high concentration of $250 \mu \mathrm{g} / \mathrm{ml}$ were moderately toxic.

As described, we selected quercetin as a model drug. Quercetin is one of the most prevalent as well as thoroughly studied dietary flavonoids with several biological and pharmacological properties. Evidence indicates that quercetin has a variety of anti-cancer mechanisms, including anti-proliferative, pro-apoptotic, cell signalling effects, and growth factor suppression, as well as potential synergism with some chemotherapeutic agents [32,51]. Quercetin also exhibits anti-inflammatory, antioxidant, and anti-viral activities [33]. Moreover, it has a role in reversing drug resistance, re-sensitizing cancer cells to some chemotherapeutic agents and in potentiating the effectiveness of some chemotherapeutic agents [52]. However, realizing the therapeutic benefits of quercetin in the clinical setting is hampered by its low solubility $(\sim 2 \%)$ in aqueous medium and poor absorption in the body. Thus, the low bioavailability and poor solubility in aqueous medium are major concerns associated with the therapeutic application of quercetin [51,52]. Similar limitations apply to experimental evaluation of quercetin's effect on cultured human cells in biological medium, and therefore quercetin alone could not be used for comparison in the present study. The MNP carrier system developed in the present study was appropriate in this regard; and therefore, the ability of quercetin to inhibit lung cancer cell growth was evaluated in comparative analysis of non-functionalized and drugloaded PLGA-MNPs. 
Administration of the MNPs resulted in elevated levels of GSH in lung tissue, an indicator of oxidative stress [53], but this was not observed to be consistently elevated over the follow-up period of 7 days unlike the LPS control. IL-6, which acts as both a pro-inflammatory and anti-inflammatory cytokine [54], and is secreted by Tcells and macrophages to stimulate an immune response during infection and after tissue trauma was also investigated as a marker of immune response. The LPS caused a significant increase in IL-6 levels in BAL samples 1 day after treatment as expected, but this was not replicated in the case of the MNPs. In fact the IL- 6 levels in BAL samples from mice exposed to MNP or PLGAMNP were comparable to those observed after administration of normal saline solution in control groups. IL-6 levels in blood plasma (data not shown) were of a much lower level and more variable indicating the localized nature of the response in the pulmonary tissue. This is in agreement with the in vitro results discussed above. Previously it has been shown that intranasal delivery of iron nanoparticles can lead to an increase in inflammatory markers including IL-6 [55]. PLGA particles themselves have been shown to have a low propensity to cause immune responses when delivered directly to the lung [56]. The biocompatible MNPs developed in this work may also be potentially exploited for targeting using external magnetic fields as demonstrated recently in nebulized mice [57].

Regional chemotherapy has been proposed as a treatment modality in a number of disease situations in order to increase exposure of the target tissues to the drug, while minimising systemic side-effects. Administration of drugs directly via inhalation allows localized drug delivery to the lungs and airways with smaller doses and minimal systemic toxicity [58]. An additional reason for maximising total deposition and targeting drugs to their desired location is to improve the cost effectiveness of drug delivery [59]. There is now increasing evidence to support the role of inhalation therapeutics in the treatment of various lung diseases. For example in lung cancer, nebulization therapeutics could be useful in 1) unresectable bronchioloalveolar carcinoma or main bronchus carcinoma with limited invasion, 2) endobronchial tumour relapse after surgery, 3) in situ carcinoma or synchronous, or 4) metachronous lesions in patients where a lesion has already been detected. However, few studies have documented the feasibility of applying nanotechnology for inhalation delivery of anticancer agents [60]. Therefore, new aerosol delivery technologies are currently being developed to meet these goals of improved targeting, reduced waste and improved patient compliance. Vibrating mesh-based nebulizers (e.g., Aerogen nebulizer) can allow for sensitive tracking of flows or pressures during breathing manoeuvres and offer the potential for high efficiency delivery of aerosolized medications. These nebulizers have been used for breath actuated high efficiency aerosol delivery during mechanical ventilation of humans and rodents [61,62]. Appropriate aerosol actuation during defined portions of the breath, allow for aerosol-free intervals, if required, thus avoiding drug deposition in the dead space of the patient interface, and even targeting of specific potions of the lung, e.g., introducing the aerosol in a small bolus at the end of inspiration to target the upper airways. Although the customizable vibrating mesh-type nebulizers have not been applied clinically to deliver MNP-based cancer therapeutics to the lung heretofore, the present study provides proof of principle for such targeting.

\section{Conclusion}

Here, we report the development of a surface engineered magnetic core-shell nanoparticle-based drug delivery system designed for aerosol therapy of lung diseases. We present a series of in vitro and in vivo investigations that were carried out to evaluate the biocompatibility of the developed nanocarrier and the feasibility of pulmonary delivering quercetin-loaded MNPs by nebulization. The data presented here demonstrate inhibition of lung adenocarcinoma growth by aerosol delivery of quercetin loaded in the PLGA-MNPs. Further in vivo studies are required to determine the optimal dosage and frequency of aerosol administrations and to assess the anticancer effect of nanoencapsulated aerosolised chemotherapy on established tumours. With the on-going efforts to enhance MNP's targeting ability, endow more functions and administration routes, their future holds great promise for advanced drug delivery applications.

\section{Methods \\ MNP preparation}

$\mathrm{FeCl}_{2}(12 \mathrm{mM})$ and $\mathrm{FeCl}_{3}(24 \mathrm{mM})$ were dissolved in 25 $\mathrm{ml} \mathrm{HCl}(0.4 \mathrm{M})$ solution. The precursors were added drop-wise to a degassed $0.5 \mathrm{M} \mathrm{NaOH}$ solution at $40^{\circ} \mathrm{C}$. The mixture was stirred for $1 \mathrm{~h}$, and then cooled to room temperature. The MNPs were subjected to magnetic separation and then washed repeatedly with water until neutral $\mathrm{pH}$ was reached. Next, MNPs were surface coated by $\mathrm{o} / \mathrm{w}$ emulsification of $4 \mathrm{ml}$ acetone:dichloromethane (1:2) contained $100 \mathrm{mg}$ PLGA (Sigma-Aldrich Ireland Ltd., Wicklow, Ireland), $50 \mu \mathrm{l}$ of $10 \mathrm{mg} / \mathrm{ml} \mathrm{MNP}$, and $20 \mathrm{mg}$ quercetin (where appropriate). The mixture was added to $12 \mathrm{ml}$ of $0.3 \%$ polyvinyl alcohol aqueous solution $(15,000 \mathrm{~g} / \mathrm{M})$. The mixture was emulsified under a sonic tip for 30 seconds, the emulsion was then added to $50 \mathrm{ml}$ of $0.3 \%$ polyvinyl alcohol solution and stirred overnight to remove the organic phase. The suspension was then centrifuged at $3000 \mathrm{~g}$ and subsequently 
re-dispersed in water several times to remove excess polyvinyl alcohol.

\section{Transmission electron microscopy (TEM)}

Samples for TEM were prepared by deposition and drying of a drop of the powder dispersed in ultrapure water onto a formvar coated 400 mesh copper grids. High resolution TEM images were acquired using an FEITitan TEM.

\section{Dynamic light scattering (DLS) measurements}

DLS measurements were performed using a Malvern Zetasizer Nano Series V5.10. The concentration of samples used for these measurements typically corresponded to an approximate absorbance of $0.2 \mathrm{~nm}$. Three measurements were usually taken for each sample and then averaged.

\section{Cell culture and treatments}

Human alveolar epithelial cells (A549 cell line, European Collection of Cell Cultures, Salisbury, UK) were cultured as described [47]. Briefly, cells were cultured in Gibco ${ }^{\circledR}$ Ham's F12 medium supplemented with $10 \%(\mathrm{v} / \mathrm{v})$ foetal bovine serum, 10,000U penicillin and $10 \mathrm{mg} / \mathrm{ml}$ streptomycin in $5 \% \mathrm{CO}_{2}$ at $37^{\circ} \mathrm{C}$ in a humidified incubator. For experimentation, cells were seeded in 96-well plates at the density of $4 \times 10^{3} \mathrm{cell} /$ well and allowed to grow overnight prior to treatment. Nanoparticles were dispersed in PBS to make a stock solution of $1 \mathrm{mg} / \mathrm{ml}$ and then diluted in cell culture medium prior to administration to the cells. Serial dilutions were established by mixing equal volumes of particle suspension and cell culture medium followed by vigorous vortexing, and applied to the cells immediately. The cell culture media and supplements were from Life Technologies Corporation (BioSciences, Dublin, Ireland).

\section{High Content Screening (HCS) and analysis}

HCS protocols for nanotoxicity studies have been optimized and established in our laboratory as described [46,47,63-68]. Briefly, A549 cells were seeded in 96-well plates $\left(4 \times 10^{3}\right.$ cells/well), exposed to various concentrations of MNP preparations for varying time-points (as indicated in the text and corresponding figure legends) at $37^{\circ} \mathrm{C}$ and $5 \% \mathrm{CO}_{2}$. After washing three times with PBS, cells were fixed by incubating them for $20 \mathrm{~min}$ with $3 \%$ paraformaldehyde. Adherent cells were then fluorescently stained with rhodamine labelled phalloidin to visualize the cellular morphology and Hoechst to visualize the nuclei. Plates were scanned (five randomly selected fields/well) using an automated microscope IN Cell Analyzer 1000 (GE Healthcare, UK) and the acquired images were automatically analysed by IN Cell Investigator (version 1.6) software using multi-parameter cytotoxicity bio-application module (GE Healthcare, UK).

\section{Real-time impedance sensing}

The dynamic monitoring of electrical impedance (which depends on cell number, degree of adhesion, spreading and proliferation of the cells) to determine cytotoxic effects of MNPs was performed using Real-Time Cell Analyzer DP instrument as per manufacturer's instructions (xCELLigance system, Roche Applied Science, West Sussex, UK) and described previously $[47,68,69]$. Briefly, A549 cells were seeded at a density of $5 \times 10^{3}$ cells/well in $100 \mu \mathrm{l}$ medium in the E-Plates 16 (cross interdigitated micro-electrodes integrated on the bottom of 16-well tissue culture plates by micro-electronic sensor technology) and allowed to attach onto the electrode surface over time. The electrical impedance was recorded every 15 minutes. At $20 \mathrm{~h}$ time point, when cells adhered to the well properly, they were treated with MNP preparations in triplicate and monitored for a further $76 \mathrm{~h}$ to record changes in cell behaviour. To ensure the MNP preparations did not interfere with the impedance measurements, control wells containing medium only and corresponding MNP samples were run in parallel. The cell impedance, expressed as an arbitrary unit called the 'Cell Index', were automatically calculated on the xCELLigence system and converted into growth curves.

\section{MNP delivery to lung epithelial cells by nebulization}

The delivery of the engineered MNP preparations to A549 lung cancer cells by nebulization was performed using a proprietary vibrating mesh-type nebulizer (Aeroneb $^{\circledR}$ Pro nebulizer system, Aerogen, Galway Business Park, Ireland) (volumetric mean diameter $3.65 \mu \mathrm{m}$ and nebulizer flow rate $0.190 \mathrm{ml} / \mathrm{min}$ with normal saline) as per manufacturer's instructions. Briefly, A549 cells were seeded in 96-well plates $\left(4 \times 10^{3}\right.$ cells/well $)$ and allowed to adhere for $24 \mathrm{~h}$. Cells were exposed to nanoparticles either by directly pip petting or nebulizing media containing varying concentrations of MNPs (as indicated in the text and corresponding figure legends) into the wells. Following exposure, cells were incubated for a further $24 \mathrm{~h}$ and the number of viable adherent cells was quantified by HCS assay as described above.

\section{In vivo biocompatibility testing of MNPs}

Six to eight week old female Balb/c mice (Harlan, UK) were allowed to acclimatise for two weeks before the initiation of the study. For all the in vivo experiments, ethical approval was obtained from the internal Ethics Committee of University College Cork, Ireland. Mice were treated intranasally with $50 \mu \mathrm{l}$ solution containing $1 \mathrm{mg} / \mathrm{ml}$ of MNP preparations. LPS $(50 \mu \mathrm{g} / \mathrm{ml})$ was 
administered similarly as a positive control, since it is known to be a potent initiator of acute lung injury [70]. Mice were euthanized at 1, 4 and 7 days post-treatment and the lungs were excised. Tissue was homogenised in $50 \mathrm{mM}$ MES buffer followed by centrifugation. The supernatant was then deproteinated and glutathione levels were determined using a Glutathione Assay Kit as per manufacturer's protocol (Cayman Chemical Company, MI, USA). BAL fluid was obtained to assess the IL-6 levels. Mice euthanized at 1, 4 and 7 days posttreatment were dissected to expose the trachea. A small incision was made in the trachea and $1 \mathrm{ml}$ of cold sterile saline was loaded into the lung and immediately removed. This was centrifuged at $3000 \mathrm{~g}$ for $10 \mathrm{~min}$ to remove cellular material. The supernatant was assayed for IL-6 levels using an IL-6 ELISA kit as per manufacturer's protocol (eBioscience, UK).

\section{Statistical analysis}

Each experiment was repeated a minimum of three times. The data are expressed as mean \pm SEM. For comparison of two groups, $p$-values were calculated using the two-tailed student's $t$-test. In all cases, statistical significance was accepted at a level of $p$-values $<0.05$.

\section{Abbreviations}

BAL: Bronchoalveolar lavage; DLS: Dynamic light scattering; HCS: High content screening; LPS: Lipopoysaccharide; MNP: Magnetic nanoparticles; PBS: Phosphate-buffered saline; PLGA: Poly(lactic-co-glycolic acid); TEM: Transmission electron microscopy.

\section{Competing interests}

The authors declare that they have no competing interests.

\section{Authors' contributions}

NKV carried out in vitro cytocompatibility studies, participated in the conception of the study, and drafted the manuscript. KCS performed in vitro nebulization experiments. AS and SG designed and synthesized all the nanoparticles used in this study. KBR oversaw the in vivo experimentation and both KBR and TD were involved in the conception and performance of the in vivo studies. CM, RM, PG and CSB participated in the critical assessment of the data, and helped to draft the manuscript. YV and YKG supervised the study, participated in the data analysis and drafting of the manuscript. All authors have read and approved the final manuscript.

\section{Acknowledgements}

High resolution TEM images were acquired with the help of Dr. Marcus Bose (Advanced Microscopy Laboratory, Trinity College Dublin, Ireland). This research was supported in part by funding from the Competence Centre in Applied Nanotechnology (CCAN, NanoMedic), Enterprise Ireland, MULTIFUN FP-7 NMP LSP 262943, Science Foundation Ireland (SFI), Centre for Research on Adaptive Nanostructures and Nanodevices (CRANN) and Aerogen.

\section{Author details}

${ }^{1}$ Department of Clinical Medicine, Institute of Molecular Medicine, Trinity College Dublin, Dublin, Ireland. ${ }^{2}$ Centre for Research on Adaptive Nanostructures and Nanodevices, Trinity College Dublin, Dublin, Ireland. ${ }^{3}$ Department of Chemistry, Trinity College Dublin, Dublin, Ireland. ${ }^{4}$ School of Pharmacy, University College Cork, Cork, Ireland. ${ }^{5}$ Aerogen, Galway Business Park, Dangan, Galway, Ireland. ${ }^{6}$ Tyndall National Institute, University College Cork, Cork, Ireland. ${ }^{7}$ Dublin City University, Dublin, Ireland.

Received: 8 November 2012 Accepted: 18 January 2013 Published: 23 January 2013

\section{References}

1. Shao H, Min C, Issadore D, Liong M, Yoon TJ, Weissleder R, Lee H: Magnetic nanoparticles and microNMR for diagnostic applications. Theranostics 2012, 2:55-65.

2. Gupta AK, Gupta M: Synthesis and surface engineering of iron oxide nanoparticles for biomedical applications. Biomaterials 2005, 26:3995-4021

3. Xie J, Huang J, Li X, Sun S, Chen X: Iron oxide nanoparticle platform for biomedical applications. Curr Med Chem 2009, 16:1278-1294.

4. Xie J, Liu G, Eden HS, Ai H, Chen X: Surface-engineered magnetic nanoparticle platforms for cancer imaging and therapy. Acc Chem Res 2011, 44:883-892.

5. Corr S, Gun'ko YK, Douvalis A, Venkatesan M, Gunning R, Nellist P: From nanocrystals to nanorods: new iron oxide-silica nanocomposites from metallorganic precursors. J Phys Chem C 2008, 112:1008-1018.

6. Nowostawska M, Corr SA, Byrne SJ, Conroy J, Volkov Y, Gun'ko YK: Porphyrin-magnetite nanoconjugates for biological imaging. J Nanobiotechnol 2011, 9:13.

7. Tiefenauer LX: Magnetic nanoparticles as contrast agents for medical diagnosis. In Nanotechnology in Biology and Medicine. Methods, Devices, and Applications. Chapter 29. Edited by Vo-Dinh T: CRC Press; 2007:1-20.

8. Wang YX, Hussain SM, Krestin GP: Superparamagnetic iron oxide contrast agents: physicochemical characteristics and applications in MR imaging. Eur Radiol 2001, 11:2319-2331.

9. Akbarzadeh A, Samiei M, Davaran S: Magnetic nanoparticles: preparation, physical properties, and applications in biomedicine. Nanoscale Res Lett 2012, 7:144.

10. Byrne SJ, Corr SA, Gun'ko YK, Kelly JM, Brougham DF, Ghosh S: Magnetic nanoparticle assemblies on denatured DNA show unusual magnetic relaxivity and potential applications for MRI. Chem Comm 2004, 22:2560-2561.

11. Corr SA, Byrne SJ, Tekoriute R, Meledandri CJ, Brougham DF, Lynch M Kerskens C, O'Dwyer L, Gun'ko YK: Linear assemblies of magnetic nanoparticles as MRI contrast agents. J Amer Chem Soc 2008, 130:4214-4215.

12. Akbarzadeh A, Mikaeili H, Zarghami N, Mohammad R, Barkhordari A Davaran S: Preparation and in vitro evaluation of doxorubicin-loaded $\mathrm{Fe}_{3} \mathrm{O}_{4}$ magnetic nanoparticles modified with biocompatible copolymers. Int J Nanomed 2012, 7:511-526.

13. Douziech-Eyrolles L, Marchais H, Hervé K, Munnier E, Soucé M, Linassier C, Dubois $P$, Chourpa I: Nanovectors for anticancer agents based on superparamagnetic iron oxide nanoparticles. Int J Nanomedicine 2007, 2:541-550.

14. Corot $C$, Robert $P$, Idée JM, Port M: Recent advances in iron oxide nanocrystal technology for medical imaging. Adv Drug Deliv Rev 2006, 58:1471-1504.

15. Huh YM, Jun YW, Song HT, Kim S, Choi JS, Lee JH, Yoon S, Kim KS, Shin JS, Suh JS, Cheon J: In vivo magnetic resonance detection of cancer by using magnetic nanocrystals. J Am Chem Soc 2005, 127:12387-12391.

16. Weissleder R, Kelly K, Sun EY, Shtatland T, Josephson L: Cell-specific targeting of nanoparticles by multivalent attachment of small molecules. Nat Biotechnol 2005, 23:1418-1423.

17. Corr S, Gun'ko YK: Multifunctional magnetic-fluorescent nanocomposites for biomedical applications. Nanoscale Res Lett 2008, 3:87-104.

18. McCarthy JE, Prina-Mello A, Rakovich T, Volkov Y, Gun'ko YK: Fabrication and characterization of multimodal magnetic - fluorescent polystyrene nanowires as selective cell imaging probes. J Mater Chem 2011, 21:14219-14225.

19. Davies GL, Corr SA, Meledandri CJ, Briode L, Brougham DF, Gun'ko YK: NMR relaxation of water in nanostructures: analysis of ferromagnetic cobaltferrite polyelectrolyte nanocomposites. Chemphyschem 2011, 12:772-776.

20. Gallagher JJ, Tekoriute R, O'Reilly JA, Kerskens C, Gun'ko YK, Lynch M: Bimodal magnetic-fluorescent nanostructures for biomedical applications. J Mater Chem 2009, 19:4081-4084.

21. Corr SA, Gun'ko YK, Tekoriute R, Meledandri CJ, Brougham DF: Poly(sodium4-styrene)sulfonate - iron-oxide nanocomposite dispersions with controlled magnetic resonance properties. J Phys Chem C 2008, 112:13324-13327.

22. Corr SA, O'Byrne A, Gun'ko YK, Ghosh S, Brougham DF, Mitchell S, Volkov Y, Prina-Mello A: Magnetic-fluorescent nanocomposites for biomedical multitasking. Chem Comm 2006, 43:4474-4476. 
23. O'Riordan TG: Aerosol delivery devices and obstructive airway disease. Expert Rev Med Devices 2005, 2:197-203.

24. Hagerman JK, Hancock KE, Klepser ME: Aerosolised antibiotics: a critical appraisal of their use. Expert Opin Drug Deliv 2006, 3:71-86.

25. Rao RD, Markovic SN, Anderson PM: Aerosol therapy for malignancy involving the lungs. Curr Cancer Drug Targets 2003, 3:239-250.

26. Zarogoulidis P, Chatzaki E, Porpodis K, Domvri K, Hohenforst-Schmidt W, Goldberg EP, Karamanos N, Zarogoulidis K: Inhaled chemotherapy in lung cancer: future concept of nanomedicine. Int J Nanomedicine 2012, 7:1551-1572.

27. Dames P, Gleich B, Flemmer A, Hajek K, Seidl N, Wiekhorst F, Eberbeck D, Bittmann I, Bergemann C, Weyh T, Trahms L, Rosenecker J, Rudolph C: Targeted delivery of magnetic aerosol droplets to the lung. Nat Nanotechnol 2007, 2:495-499.

28. Gagnadoux F, Hureaux J, Vecellio L, Urban T, Le Pape A, Valo I, Montharu J, Leblond V, Boisdron-Celle M, Lerondel S, Majoral C, Diot P, Racineux JL, Lemarie E: Aerosolized chemotherapy. J Aerosol Med Pulm Drug Deliv 2008, 21:61-70.

29. Roa WH, Azarmi S, Al-Hallak MH, Finlay WH, Magliocco AM, Löbenberg R: Inhalable nanoparticles, a non-invasive approach to treat lung cancer in a mouse model. J Control Release 2011, 150:49-55.

30. Otterson GA, Villalona-Calero MA, Sharma S, Kris MG, Imondi A, Gerber M, White DA, Ratain MJ, Schiller JH, Sandler A, Kraut M, Mani S, Murren JR: Phase I study of inhaled Doxorubicin for patients with metastatic tumors to the lungs. Clin Cancer Res 2007, 13:1246-1252.

31. Otterson GA, Villalona-Calero MA, Hicks W, Pan X, Ellerton JA, Gettinger SN, Murren JR: Phase I/II study of inhaled doxorubicin combined with platinum-based therapy for advanced non-small cell lung cancer. Clin Cancer Res 2010, 16:2466-2473.

32. Zheng SY, Li Y, Jiang D, Zhao J, Ge JF: Anticancer effect and apoptosis induction by quercetin in the human lung cancer cell line A-549. Mol Med Report 2012, 5:822-826.

33. Di Carlo G, Mascolo N, Izzo A, Capasso F: Flavonoids: old and new aspects of a class of natural therapeutic drugs. Life Sci 1999, 65:337-353.

34. Pandey R, Sharma A, Zahoor A, Sharma S, Khuller GK, Prasad B: Poly (DL-lactide-co-glycolide) nanoparticle-based inhalable sustained drug delivery system for experimental tuberculosis. J Antimicrob Chemother 2003, 52:981-986.

35. Park J, Fong PM, Lu J, Russell KS, Booth KJ, Saltzman WM, Fahmy TM: PEGylated PLGA nanoparticles for the improved delivery of doxorubicin. Nanomedicine (Lond) 2009, 5:410-418.

36. Arruebo M, Fernández-Pacheco R, Ibarra MR, Santamaría J: Magnetic nanoparticles for drug delivery. Nano Today 2007, 2:22-32.

37. Neuberger T, Schopf B, Hofmann H, Hofmann M, Von Rechenberg B: Superpara-magnetic nanoparticles for biomedical applications: possibilities and limitations of a new drug delivery system. J Magn Magn Mater 2005, 293:483-496.

38. Grassi-Schultheiss PP, Heller F, Dobson J: Analysis of magnetic material in the human heart, spleen and liver. Biometals 1997, 10:351-355.

39. Alexiou C, Tietze R, Schreiber E, Jurgons R, Richter H, Trahms L, Rahn H, Odenbach S, Lyer S: Cancer therapy with drug loaded magnetic nanoparticles-magnetic drug targeting. J Magn Magn Mater 2011, 323:1404-1407.

40. Tietze R, Lyer S, Dürr S, Alexiou C: Nanoparticles for cancer therapy using magnetic forces. Nanomedicine (Lond) 2012, 7:447-457.

41. McCarthy JR, Weissleder R: Multifunctional magnetic nanoparticles for targeted imaging and therapy. Adv Drug Deliv Rev 2008, 60:1241-1251.

42. Laurent S, Forge D, Port M, Roch A, Robic C, Elst LV, Muller RN: Magnetic iron oxide nanoparticles: synthesis, stabilization, vectorization, physicochemical characterizations, and biological applications. Chem Rev 2008, 108:2064-2110.

43. Singh N, Jenkins GJS, Asadi R, Doak SH: Potential toxicity of superparamagnetic iron oxide nanoparticles (SPION). Nano Rev 2010, 1:5358.

44. Kocbek P, Obermajer N, Cegnar M, Kos J, Kristl J: Targeting cancer cells using PLGA nanoparticles surface modified with monoclonal antibody. J Control Release 2007, 120:18-26.

45. Lin W, Huang YW, Zhou XD, Ma Y: In vitro toxicity of silica nanoparticles in human lung cancer cells. Toxicol Appl Pharmacol 2006, 217:252-259.

46. Mohamed BM, Verma NK, Prina-Mello A, Williams Y, Davies AM, Bakos G, Tormey L, Edwards C, Hanrahan J, Salvati A, Lynch I, Dawson K, Kelleher D,
Volkov $Y$ : Activation of stress-related signalling pathway in human cells upon $\mathrm{SiO}_{2}$ nanoparticles exposure as an early indicator of cytotoxicity. J Nanobiotechnol 2011, 9:29.

47. Verma NK, Moore E, Blau W, Volkov Y, Ramesh Babu P: Cytotoxicity evaluation of nanoclays in human epithelial cell line A549 using high content screening and real-time impedance analysis. J Nanopart Res 2012, 14:1137.

48. Ekstrand-Hammarström B, Akfur CM, Andersson PO, Lejon C, Österlund L, Bucht A: Human primary bronchial epithelial cells respond differently to titanium dioxide nanoparticles than the lung epithelial cell lines A549 and BEAS-2B. Nanotoxicol 2012, 6:623-634.

49. Solly K, Wang X, Xu X, Strulovici B, Zheng W: Application of real-time cell electronic sensing (RT-CES) technology to cell-based assays. Assay Drug Dev Technol 2004, 2:363-372.

50. Wegener J, Keese CR, Giaever I: Electric cell-substrate impedance sensing (ECIS) as a noninvasive means to monitor the kinetics of cell spreading to artificial surfaces. Exp Cell Res 2000, 259:158-166.

51. Kelly GS: Quercetin. Monograph. Altern Med Rev 2011, 16:172-194.

52. Graefe EU, Derendorf H, Veit M: Pharmacokinetics and bioavailability of the flavonol quercetin in humans. Int J Clin Pharmacol Ther 1999, 37:219-233.

53. Anderson ME: Glutathione: an overview of biosynthesis and modulation. Chem Biol Interact 1998, 111-112:1-14.

54. Scheller J, Chalaris A, Schmidt-Arras D, Rose-John S: The pro- and antiinflammatory properties of the cytokine interleukin-6. Biochim Biophys Acta 2011, 1813:878-888.

55. Park EJ, Kim H, Kim Y, Yi J, Choi K, Park K: Inflammatory responses may be induced by a single intratracheal instillation of iron nanoparticles in mice. Toxiciology 2010, 275:65-71

56. Hara K, Tsujimoto H, Tsukada Y, Huang CC, Kawashima Y, Tsutsumi M: Histological examination of PLGA nanospheres for intratracheal drug administration. Int J Pharm 2008, 356:267-273.

57. Hasenpusch G, Geiger J, Wagner K, Mykhaylyk O, Wiekhorst F, Trahms L, Heidsieck A, Gleich B, Bergemann C, Aneja MK, Rudolph C: Magnetized aerosols comprising superparamagnetic iron oxide nanoparticles improve targeted drug and gene delivery to the lung. Pharm Res 2012, 29:1308-1318.

58. Bennett WD: Controlled inhalation of aerosolised therapeutics. Expert Opin Drug Deliv 2005, 2:763-767.

59. Brand P, Beckmann H, Maas Enriquez M, Meyer T, Müllinger B, Sommerer $K$ Weber N, Weuthen T, Scheuch G: Peripheral deposition of a1-protease inhibitor using commercial inhalation devices. Eur Respir J 2003, 22:263-267.

60. Sharma S, White D, Imondy AR, Placke ME, Vail DM, Kris MG: Development of inhalational agents for oncologic use. J Clin Oncol 2001, 19:1839-1847.

61. Dhand R, Sohal H: Pulmonary Drug Delivery System for inhalation therapy in mechanically ventilated patients. Expert Rev Med Devices 2008 5:9-18.

62. MacLoughlin RJ, Higgins BD, Laffey JG, O'Brien T: Optimized aerosol delivery to a mechanically ventilated rodent. J Aerosol Med Pulm Drug Deliv 2009, 22:323-332.

63. Mohamed BM, Verma NK, Davies AM, McGowan A, Crosbie-Staunton K Prina-Mello A, Kelleher D, Botting CH, Causey CP, Thompson PR, Pruijn GJ, Kisin ER, Tkach AV, Shvedova AA, Volkov Y: Citrullination of proteins: a common post-translational modification pathway induced by different nanoparticles in vitro and in vivo. Nanomedicine (Lond) 2012, 7:1181-1195.

64. Jan E, Byrne SJ, Cuddihy M, Davies AM, Volkov Y, Gun'ko YK, Kotov NA: High-content screening as a universal tool for fingerprinting of cytotoxicity of nanoparticles. ACS Nano 2008, 2:928-938.

65. Long A, Volkov Y: High content analysis approach for targeted gene silencing and probing nanoscale cell responses. Eur Pharm Rev 2009, 1:22-30.

66. Byrne F, Prina-Mello A, Whelan A, Mohamed BM, Davies A, Gun'ko Y, Coey JMD, Volkov Y: High content analysis of the biocompatibility of nickel nanowires. J Magn Magn Mater 2009, 321:1341-1345.

67. Movia D, Prina-Mello A, Volkov Y, Giordani S: Determination of spiropyran cytotoxicity by high content screening and analysis for safe application in bionanosensing. Chem Res Toxicol 2010, 23:1459-1466.

68. Verma NK, Conroy J, Lyons PE, Coleman J, O'Sullivan MP, Kornfeld H, Kelleher D, Volkov Y: Autophagy induction by silver nanowires: A new aspect in the biocompatibility assessment of nanocomposite thin films. Toxicol Appl Pharmacol 2012, 264:451-461. 
69. Lysaght J, Verma NK, Maginn EN, Ryan JM, Campiani G, Zisterer DM, Williams DC, Browne PV, Lawler MP, McElligott AM: The microtubule targeting agent PBOX-15 inhibits integrin-mediated cell adhesion and induces apoptosis in acute lymphoblastic leukaemia cells. Int J Oncol 2013, 42:239-246.

70. Hassett P, Curley GF, Contreras M, Masterson C, Higgins BD, O'Brien T, Devaney J, O'Toole D, Laffey JG: Overexpression of pulmonary extracellular superoxide dismutase attenuates endotoxin-induced acute lung injury. Intensive Care Med 2011, 37:1680-1687.

doi:10.1186/1477-3155-11-1

Cite this article as: Verma et al: Magnetic core-shell nanoparticles for drug delivery by nebulization. Journal of Nanobiotechnology 2013 11:1.

\section{Submit your next manuscript to BioMed Central and take full advantage of:}

- Convenient online submission

- Thorough peer review

- No space constraints or color figure charges

- Immediate publication on acceptance

- Inclusion in PubMed, CAS, Scopus and Google Scholar

- Research which is freely available for redistribution 